\title{
KAJIAN MANAJEMEN DARURAT VIRUS CORONA DAN MENJAGA KESINAMBUNGAN BISNIS
}

\author{
The Coronavirus Emergency Management And Maintaining Business Continuity \\ Bambang Hirawan
}

PT SIM ADITAMA KARYA

J. Letda M Natsir Blok E No 19, Gunung Putri Bogor 16969

E-mail: bambangdua74@gmail.com

\begin{abstract}
Abstrak
Wabah pandemi Coronavirus (COVID-19) telah mempengaruhi bisnis di seluruh dunia.Tidak sedikit negara yang merasa kewalahan dalam mempertahankan kesehatan warga dan menyelamatkan perekonomiannya. Untuk mengatasi dampak pandemi terhadap perekonomian tersebut, maka pertama-tama harus dipastikan perusahaanperusahaan dapat bertahan dan ditata kembali dengan menerapkan 4 prinsip utama dalam penataan perusahaan (International Chamber of Commerce, 2020), yaitu: Plan, Adapt, Monitor dan Assess (PAMA). Tujuan dari penelitian adalah untuk menganalisa kesiapsiagaan perusahaan dimasa pandemic COVID-19 dan langkahlangkah dalam menjaga keberlangsungan usahanya. Penelitian dilakukan dengan metode pengamatan terhadap web perusahaan untuk mendapatkan informasi tentang kebijakan 14 perusahaan dalam pencegahan penyebarluasan Coronavirus di lingkungan kerjanya, serta kondisi perusahaan dan upaya-upaya yang dilakukan untuk terus melangsungkan usaha. Selain itu, juga dilakukan Focus Group Discussion (FGD) dengan para ahli Keselamatan dan Kesehatan Kerja (K3), dan Emergency Management System untuk mendapatkan pandangan tentang usaha-usaha untuk bertahan dan menjaga kelangsungan usaha. Secara umum, perusahaan-perusahaan itu telah menunjukkan penerapan prinsip PAMA. Dari pengamatan dan analisis terhadap Emergency Response Plans (ERP) masing-masing perusahaan ditengarai telah menyelenggarakan program-program kedaruratan sesuai dengan situasi dan kondisi yang dihadapinya, dan program-program yang menjaga kelangsungan perusahaan didasarkan pada kemampuan perusahaan. Dari uraian di atas, dapat disimpulkan bahwa 14 perusahaan yang diamati telah memiliki Emergency Response Plans (ERP) dan program-program kedaruratan, meski tampak belum ada kesatuan standar, selain itu perusahaan tersebut telah melakukan program-program untuk menjaga keberlangsungan usaha berdasarkan kemampuan perusahaan dan inti bisnisnya.
\end{abstract}

Kata Kunci: PAMA, Emergency Response Plan (ERP), Kesinambungan bisnis.

\begin{abstract}
Abstrak
The Coronavirus pandemic has affected business the world. Countries feel overwhelmed in maintaining the health of citizens and saving economies. To overcome impact of pandemic on the economy, it must be ensured that companies can survive by applying 4 main principles in corporate structuring (International Chamber of Commerce, 2020): Plan, Adapt, Monitor and Assess (PAMA). The purpose of the research is to analysis the preparedness of the company during the COVID-19 pandemic and steps in maintaining business continuity. The research method was carried out by observing the company's web related to 14 company policies in preventing the spread of Coronavirus in the work environment, Focus Group Discussion with experts on Occupational Safety and Health, an Emergency Management System. Companies have demonstrated the application of the PAMA principles. From observations and analysis of the Emergency Response Plans, each company is suspected of carrying out emergency programs in accordance with the company's condition, and programs that maintain the company's continuity based on the company's capabilities. It can be concluded that 14 companies have Emergency Response Plans, although there is not standard unity yet and the company has implemented programs that maintain business continuity.
\end{abstract}

Key words: PAMA, Emergency Response Plans, Business Continuity.

\section{PENDAHULUAN}

Biohazard yang berasal dari Coronavirus (COVID-19) sangat berbahaya dan penyebarannya berlangsung sangat cepat keseluruh dunia. Biohazard tersebut dapat menular kedalam tubuh manusia melalui mulut, kontak kulit, luka tusuk dan melalui hidung. (Roger L Brauer, 2016). COVID-19 menciptakan ancaman pada keselamatan manusia bahkan telah menelan korban jiwa, menimbulkan krisis ekonomi dan menurunkan ketahanan sosial 
masyarakat. Menurut menteri Keuangan Sri Mulyani mengatakan, kebijakan pembatasan aktivitas sosial berdampak pada penurunan ekonomi. Pertumbuhan ekonomi terkontraksi selama pembatasan sosial dan lockdown diterapkan di beberapa negara.

Menurut artikel di okezone (2020) Perekonomian mengalami penurunan drastis, bahkan kematian di beberapa aktivitas ekonomi dikarenakan tidak bisa beraktivitas, artinya. Aktivitas yang terganggu terjadi di dua sisi sekaligus (okezone, 2020). Penurunan ekonomi itu berdampak pada pekerja, konsumen, dan kelangsungan bisnis.

Wabah pandemi Coronavirus (COVID-19) telah mempengaruhi bisnis di seluruh dunia. Tidak sedikit negara yang merasa kewalahan dalam mempertahankan kesehatan warga dan menyelamatkan perekonomiannya. Kesiapsiagaan dan kewaspadaan merupakan faktor-faktor penentu dalam membangun bisnis dan menjaga kelangsungannya di masa pandemi ini. Perusahaan dituntut siapsiaga untuk menerapkan Incident Managament System (IMS) dan Emergency Response Plans (ERP) yang meliputi Emergency Management, Crisis Management dan Business Continuity Management demi mempertahankan keberadaan dan menjaga kelangsungan bisnisnya.

Dalam penerapan Business Continuity Management, perusahaan harus mampu melakukan Preparedness Emergency Management, cermat dalam menyusun Risk Analysis dan Business Impact Analysis (BIA), serta teliti dalam membuat Business Continuity Plans (BCP). Berdasarkan uraian tersebut, tujuan dari penelitian adalah untuk menganalisa kesiapsiagaan perusahaan dimasa pandemi COVID-19 dan langkah-langkah dalam menjaga keberlangsungan usahanya.

\section{TINJAUAN PUSTAKA}

Pandemi Coronavirus telah menggoncang perekonomian negara-negara di dunia. Berdasarkan Laporan Bappenas tentang Perkembangan Ekonomi Indonesia dan Dunia untuk Triwulan I (2020): perekonomian Negaranegara ASEAN terkontraksi (-) 0,6 persen. Sementara itu, menurut Berita Resmi Statistik 5 Agustus 2020 yang diterbitkan Badan Pusat Statistik menunjukkan bahwa perekonomian Indonesia (pertumbuhan Produk Domestik Bruto) pada Triwulan ke-2 tahun 2020 terkontraksi (-) $5,32 \%$.
Data kontraksinya pertumbuhan Produk Domestik Bruto tersebut menunjukkan bahwa perekonomian negara-negara ASEAN tidak terkecuali Indonesia mengalami kontraksi dan Negara-negara di kawasan ASEAN terancam resesi. Untuk mengatasi dampak pandemi terhadap perekonomian tersebut, maka pertamatama harus dipastikan perusahaan dapat bertahan dan ditata kembali dengan menerapkan 4 prinsip utama dalam penataan perusahaan kembali (International Chamber of Commerce, 2020), yaitu: Plan, Adapt, Monitor dan Assess (PAMA).

\subsection{Plan}

Dalam menghadapi situasi darurat (Emergency) yang kemungkinan dapat berubah menjadi bencana (Disaster), maka perusahaan harus memiliki Emergency Response Plans (ERP) yang tepat dengan memperhatikan, mengikuti dan menerapkan standar-standar yang berlaku, antara lain:

a. ISO 45001:2018

b. Draft ISO 45005

c. Sistem Manajemen Keselamatan Kesehatan Kerja (SMK3) tentang Peraturan Pemerintah No 50 Tahun 2012.

d. National Fire Protection Association (NFPA) 1600.

e. International Chamber of Commerce (ICC), Covid-19 Business Continuity Guide.

f. ISO 22301:2019, Business Continuity Management System, khususnya klausus tentang:

- Business Impact Analysis and Risk Assessment

- Business Continuity Strategies and Solutions

- Business Continuity Plans and Procedures

Perusahaan-perusahaan yang telah memiliki Emergency Response Plans (ERP) , maka dalam menghadapi Coronavirus ini perusahaan-perusahaan itu siap untuk :

a. Buat gugus tugas perusahaan tentang kesiapsiagaan pandemic di dalam perusahaan

b. Menilai pentingnya aktivitas bisnis

c. Melakukan analisis skenario kelangsungan bisnis

d. Menetapkan peran untuk aktivitas mitigasi COVID-19

e. Menetapkan strategi komunikasi internal dan external

f. Menjelajahi dan mempelajari program manajemen kelangsungan bisnis 


\section{$2.2 \quad$ Adapt}

Perusahaan

berusaha

untuk

menyesuikan diri dengan keadaan. Oleh karena itu, perusahaan membuat kebijakan yang realitis dalam menghadapi pandemi seperti :

a. melindungi keselamatan karyawan dan masyarakat sekitar,

b. membuat prosedur bekerja dari rumah (Work From Home),

c. menyesuaikan agar dapat menjaga beroperasi aman dengan protocol kesehatan.

d. Perusahaan dapat menjalankan manajemen dengan fleksibel, adaptif dan dinamik untuk menghadapi New Normal.

\subsection{Monitor}

Secara prinsip, perusahaan yang siap untuk menghadapi keadaan darurat dan siap untuk menjalankan bisnisnya akan terus melakukan (Denton, 2020):

a. Pantau terhadap keadaan tidak aman dari para pekerja mulai dari masuk kantor dengan pemeriksaan suhu tubuh, saat rapat, pengaturan bekerja shift.

b. Pantauan terhadap pembatasan penumpang dalam sarana transportasi, penguna ruangan rapat dan pekerja yang berada dalam ruang kerja.

\subsection{Assess}

Prinsip keempat, Perusahaan melakukan review terus menerus persiapan pelaksanaan rencana pandemi, dan siap untuk melakukan perbaikan yang terus menerus.

\section{METODE PENELITIAN}

Penelitian dilakukan dengan metode sebagai berikut:

a. Pengamatan terhadap web perusahaan terkait kebijakan perusahaan-perusahaan dalam pencegahan penyebarluasan Coronavirus di lingkungan kerjanya.

b. Focus Group Discussion (FGD) dengan para ahli Keselamatan dan Kesehatan Kerja (K3), dan Emergency Management System.

c. Penelitian dilakukan dengan pendekatan studi kasus pada 14 perusahaan.

\section{HASIL DAN PEMBAHASAN}

Sejumlah 14 perusahaan telah diamati dan diteliti , apakah perusahaan-perusahaan itu telah melakukan menerapkan empat prinsip utama tersebut. Pengamatan dilakukan terhadap web perusahaan dan informasi di internet, sehingga diperoleh informasi sebagai berikut:

a. PT Pertamina (Persero).

ヨumn Kepatuhan Protokol New Normal : Ke To P Ra K

Ketegasan

Melalui kebijakan sekarang Perusahaan menindak tegas pada pekerja yang melangar

Totalitas

Monitoring bukan hanya bagi Pekerjaan WFO saja. Tapi juga Pekerja WFH

Peran Atasan

Atasan diberikan peran untuk mengawasi dan memastikan pekerja yang WFH dan WFO taat pada protokol.

Responsilitas

Perusahaan meminta/menagih pertanggungjawaban pada semua pihak yang diberikan peran untuk menanggulangi Covid-19, contoh sistem random checking.

5 Peningkatan Mitigasi

Inovasi kebijakan untuk meningkatkan mitigasi penularan Convid-19,

seperti penyesuaian dengan kebijakan Ganjil Genap \& perpanjangan masa

transisi tahap 1.

Gambar 1 Komitmen pertamina bergotong royong lawan covid-19.

(Sumber: www.pertamina.com)

Adapun Program PT Pertamina (Persero) adalah sebagai berikut :

- Memastikan pasokan Bahan Bakar Minyak dan LPG dalam kondisi aman.

- Membuat sebuah gerakan gotong royong yang melibatkan seluruh pekerja, mitra kerja, dan keluarganya dengan nama Ke To P Ra K untuk kepatuhan protocol adaptasi kebiasaan baru.

- Membuat prosedur kesiapsiagaan dalam pencegahan dan penanggulangan COVID-19.

- Penerapan Sistem Manajemen menggunakan SUPREME (Sustainability Pertamina Expextation for HSSE Management Excellence)

\section{b. PT Chevron Pacific Indonesia}

Di Masa Pandemi, PT Chevron Pacific Indonesia Fokus Jaga Kegiatan Operasi

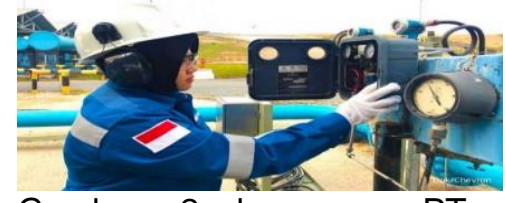

Gambar 2 karyawan PT Chevron Pacific Indonesia (PT CPI).

(Sumber : https://industri.kontan.co.id)

Program PT. Chevron Pacific Indonesia adalah sebagai berikut:

- Fokus utama Chevron saat ini adalah memastikan para karyawan dalam keadaan sehat, selamat.

- Program ketahanan pangan (pemulihan), promosi kesehatan (pencegahan), dan bantuan kesiapsiagaan kondisi darurat. 
- Menerapan Program Sistem Manajemen : OEM (Operational Excellence Management System)

\section{c. Exxon Mobil Indonesia}

Di Masa Pandemi, ExxonMobil Fokus Jaga Kegiatan Operasi

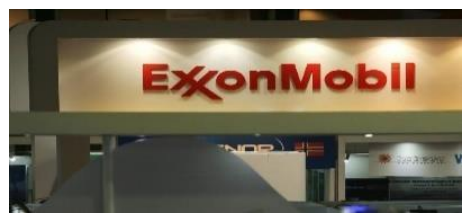

Gambar 3 Logo Exxon Mobil Corp.

(Sumber https://otomotif.tempo.co)

Program Exxon Mobil Indonesia sebagai berikut :

- Fokus untuk menjaga kegiatan operasionalnya agar kinerja keuangan perusahaan tidak menyusut

- Usaha hulu dan hilir kami terus berjalan sembari memastikan operasi yang aman dan andal

- Membentuk protokol dalam kegiatan operasional perusahaan sehari-hari guna menanggulangi penyebarang virus corona atau Covid-19

- Menerapan Program Sistem Manajemen : OIM (Operations Integrity Management System)

\section{d. British Petroleum}

Dampak Covid-19, BP Dikabarkan Akan Kurangi 10.000 Pekerja

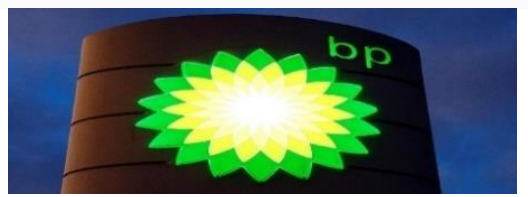

Gambar 4 British Petroleum.

(Sumber : https://www.cnbcindonesia.com)

Program British Petroleum sebagai berikut :

- Membentuk

Kesehatan dalam kegiatan operasional perusahaan.

- Program pembatasi kunjungan ke pabrik.

- Fokus menjaga kegiatan operasional dengan aman dan handal.

- Menerapan Program Sistem Manajemen :OMS (Operating Management System)

\section{e. Conocophillip (Grissik)}

ConocoPhillips Kaji Efek Covid-19 pada Permintaan Gas Blok Corridor

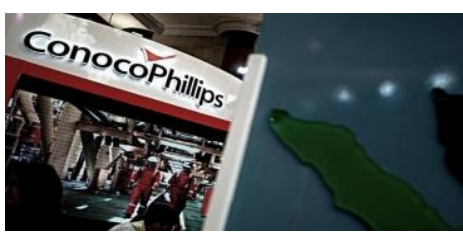

Gambar 5 Conocophillips.

(Sumber https://katadata.co.id)

Program Conocophillip (Grissik) sebagai berikut:

- Mengkaji efek CoVID-19 pada permintaan gablok corridor, memastikan komitmen jual beli gas.

- Fokus menjaga kegiatan operasional dengan aman dan handal.

- Menerapan Program Sistem Manajemen : HSEMS (Health Safety Environment Management System)

\section{f. PT Perusahaan Listrik Negara (PLN)}

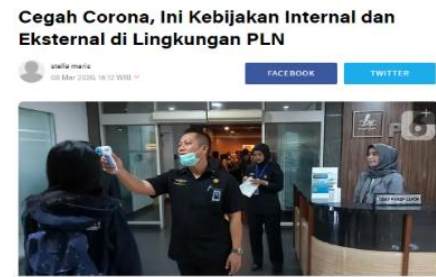

Gambar 6 Berita tentang Kebijakan Internal dan Eksternal di lingkungan PLN.

(sumber: https://www.liputan6.com)

Program PLN sebagai berikut:

- Listrik Gratis , insentif berupa pembebasan tagihan, diskon listrik, penghapusan biaya minimum, dan penghapusan abonemen.

- Menerapkan prosedur standar keamanan di lingkungan kerja

Menerapan Program Sistem Manajemen : SMLK3 (Sistem Mutu, Lingkungan, Keselamatan dan Kesehatan Kerja)

\section{g. PT Indocemen Tunggal Prakasa Tbk} Indocement Mendukung Program PSBB dalam Rangka Pencegahan Covid-19

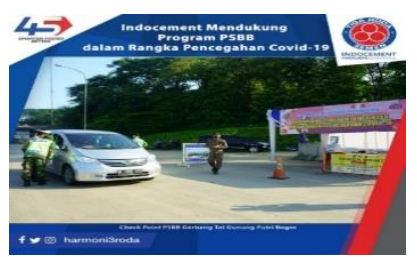

Gambar 7 Berita Kebijakan PT Indosemen Tunggal Prakarsa Tbk.

(Sumber http://www.indocement.co.id) 
Program PT Indocement Tunggal Prakasa Tbk:

- Pembentukan Gugus Tugas Pencegahan dan Penanganan Covid-19.

- Medical Response Team dan Emergency Response Plan

- Prosedur Pengaturan Kerja Bergilir dan Work From Home

- Membuat prosedur Adaptasi Kebiasaan baru dan monitoringnya.

- Menerapkan program Sistem Manajemen Kesinambungan Bisnis (Business Continuity Management System)

\section{h. PT Semen Indonesia}

Hadapi New Normal, Ini yang Dilakukan Semen Indonesia

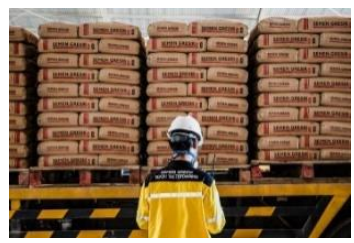

Gambar 8 PT. Seben Indonesia Tbk. (Sumber: https://money.kompas.com)

Program PT Semen Indonesia sebagai berikut:

- Melakukan proses produksi dan pengecekan hasil produksi.

- Membuat antisipasi scenario the new normal, mengenalkan platform digital pada layanan kebutuhan pembangunan.

- Melindungi masyarakat dan karyawan dengan protokol Kesehatan di seluruh area operasional perusahaan.

- Menerapkan physical distancing dan work form home (WFH).

- Menerapan Program Sistem Manajemen : Mutu , Lingkungan , Keselamatan dan Kesehatan Kerja, Manajemen Risiko.

\section{i. PT Pupuk Sriwijaya (Pusri)}

Pusri berdayakan karyawan tangkal pandemi COVID-19

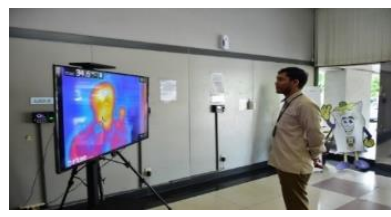

Gambar 9. PT Pupuk Sriwidjaja (Pusri) (Sumber : https://kalsel.antaranews.com)

Program PT Pupuk Sriwijaya (Pusri) sebagai berikut:
- Pelatihan COVID Drill, untuk kesiapsiagaan penangganan COVID-19.

- Pematuhan protocol kesehatan, membatasi jam kerja, melalui Work From Home.

- Menerapan Program Sistem Manajemen : Mutu , Lingkungan , Keselamatan dan Kesehatan Kerja, serta Manajemen Risiko.

\section{j. PT Candra Asri Petrochemical Tbk}

Pandemi Covid-19 tak menghalangi ekspansi

Chandra Asri Petrochemical

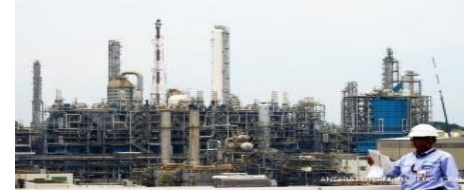

Gambar 10. PT Chandra Asri Petrochemical Tbk (Sumber https://industri.kontan.co.id)

Program PT Candra Asri Petrochemical Tbk sebagai berikut:

- Melangsungkan rencana ekspansi kapasitas produksinya pembangunan pabrik Metil TertButil Ether (MTBE).

- Mengimplementasikan jarak social dan kebijakan kerja dari rumah.

- Mendonasikan sejumlah peralatan Kesehatan yaitu Rapid test, masker N95, hazmat kepada Badan Nasional Penanggulangan Bencana (BNPB).

- Menerapan Program Sistem Manajemen : SHEQEn ( Safety Health Environment Quality Energy).

\section{k. PT PAL Indonesia}

PAL Amankan Kesinambungan Pekerjaan di Tengah Pandemi COVID-19

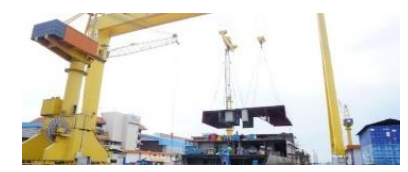

Gambar 11. PT PAL Indonesia (Sumber : https://pal.co.id)

Program PT PAL Indonesia sebagai berikut :

- Amankan-kesinambungan-pekerjaan ditengah-pandemi-covid-19.

- Penyelesaian proyek strategis seperti Kapal Bantu Rumah Sakit (BRS). 
- Pekerjaan proyek saat ini dikerjakan dengan menerapkan protokol Kesehatan.

- Menerapan Program Sistem Manajemen : Mutu, Lingkungan, Keselamatan dan Kesehatan Kerja

\section{PT Polytama Propindo}

Polytama Propindo bantu tenaga medis di Jakarta hadapi wabah

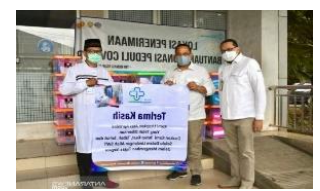

Gambar 12. Komitmen PT Polytama Propindo lawan COVID-19

(Sumber : https://www.antaranews.com)

Program PT Polytama Propindo sebagai berikut:

- Memberikan paket suplemen di bagikan kepada tenaga medis.

- Manajemen pencegahan COVID-19 namanya :"Mang COVID-19".

- Menerapan Program Sistem Manajemen : Lingkungan, memperoleh proper hijau.

\section{m. PT Pupuk Kaltim}

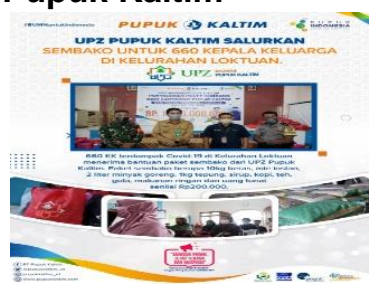

Gambar 13. PT Pupuk Kaltim memberikan Sembako

(Sumber : https://www.pupukkaltim.com)

Program PT Pupuk Kaltim sebagai berikut:
- Penerapan Sistem Manajemen integrasi Keselamatan dan Keselamatan Kerja, Quality, Lingkungan hidup, Risk Management, Anti Penyuapan.

- Memberikan vaksin influenza yang kini mencapai 300 karyawan.

- Peningkatan kapasitas Rumah Sakit

n. PT Badak LNG

Badak LNG Terapkan Status Waspada Tinggi Covid-19

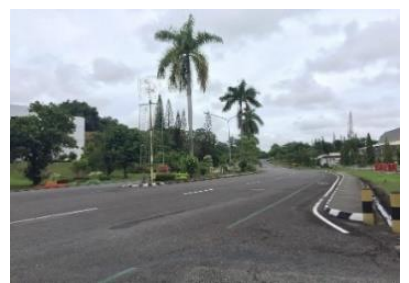

Gambar 14. Komplek Badak LNG

(Sumber: https://korankaltim.com)

Program PT Badak LNG sebagai berikut :

- Menerapan Sistem Manajemen : BSMART (Badak SHED Management System and Attitude Reinforcement Techniques)

- Menerapkan status waspada tinggi terhadap penyebaran Covid-19.

- Upaya pencegahan dengan pembatasan keluar-masuk kompleks Perusahaan

- Latihan atau exercise wabah COVID-19, bertujuan untuk mengantisipasi kesiapan penanganan wabah

- Bantuan kepada masyarakat buffer zone 10 unit wastafel cuci tangan, tandon air.

Dari 14 perusahaan yang diamati melalui Web tersebut lalu dilakukan Focus Group Discussion (FGD) dengan para ahli yang hasilnya dirangkum dalam Tabel 1, sebagai berikut:

Tabel 1 Kebijakan pencegahan penyebaran Coronavirus di Perusahaan-Perusahaan

\begin{tabular}{|c|c|c|c|}
\hline No & Nama Perusahaan & $\begin{array}{l}\text { Kebijaksanaan } \\
\text { Pencegahan }\end{array}$ & Keterangan \\
\hline 1 & PT. Pertamina & Ada & Komitmen penerapan kebijakan pencegahan KeToPRak \\
\hline 2 & PT Chevron P I & Ada & Panduan otorisasi Kesehatan,kesiapsiagaan kondisi darurat. \\
\hline 3 & Exxon Mobil & Ada & Porto folio hulu dan hilir seimbang, panduan keselamat kerja. \\
\hline 4 & British Petroleum & Ada & Protokol kegiatan operational antisipasi covid-19. \\
\hline 5 & $\begin{array}{l}\text { Conocophillips } \\
\text { (Grissik) }\end{array}$ & Ada & Memastikan jual beli gas berjalan lancar, protocol Kesehatan. \\
\hline 6 & PT PLN & Ada & $\begin{array}{l}\text { Kebijakan internal dan external, pembuatan panduan } \\
\text { pencegahan penyebaran covid-19. }\end{array}$ \\
\hline 7 & $\begin{array}{l}\text { PT Indocemen } \\
\text { Tunggal Prakasa }\end{array}$ & Ada & $\begin{array}{l}\text { Menerapkan kesinambungan bisnis, pedoman pencegahan dan } \\
\text { penanganan covid-19. }\end{array}$ \\
\hline
\end{tabular}




\begin{tabular}{|c|c|c|c|}
\hline No & Nama Perusahaan & $\begin{array}{l}\text { Kebijaksanaan } \\
\text { Pencegahan }\end{array}$ & Keterangan \\
\hline 8 & PT Semen Indonesia & Ada & $\begin{array}{l}\text { Antisipasi scenario the new normal, gugus tugas penanganan } \\
\text { covid. }\end{array}$ \\
\hline 9 & PT PUSRI & Ada & $\begin{array}{l}\text { Pelatihan Covid Drill, Melakukan pencegahan pemutusan rantai } \\
\text { covid-19. }\end{array}$ \\
\hline 10 & PT Candra Asri & Ada & Rencana ekpansi produksi, melakukan protocol kesehatan. \\
\hline 11 & PT PAL & Ada & Amankan kesinambungan proyek, menerapkan tanggap darurat \\
\hline 12 & PT Polytama & Ada & $\begin{array}{l}\text { Manajemen pencegahan Covid-19 : Mang Covid-19. Pelatihan } \\
\text { pemulihan ekonomi. }\end{array}$ \\
\hline 13 & Pupuk Kaltim & Ada & $\begin{array}{l}\text { Mendukung pencegahan covid-19 di kota Bontang, menjaga } \\
\text { operational safety. }\end{array}$ \\
\hline 14 & PT Badak LNG & Ada & $\begin{array}{l}\text { Terapkan Waspada Tinggi, utamakan proses produksi dengan } \\
\text { aman dan andal. }\end{array}$ \\
\hline
\end{tabular}

Dari data yang diperoleh dengan pengamatan Web perusahaan dan pandangan para ahli dalam FGD, selanjutnya dilakukan analisis yang dirangkum dalam Tabel 2 sebagai berikut:

Tabel 2 Analisis Kebijakan Perusahaan untuk Pencegahan Penyebaran Covid-19

\begin{tabular}{|c|c|c|}
\hline No & Nama Perusahaan & Hasil Analisa Terhadap Kebijakan Pencegahan Penyebaran Covid-19 \\
\hline 1 & PT. Pertamina & $\begin{array}{l}\text { Memastikan ketersediaan Bahan Bakar Minyak. Program gotong royong untuk } \\
\text { meningkatkan protocol New Normal dengan KeToPRak (Ketegasan, Totalitas Peran } \\
\text { Atasan, Responsibilitas, Peningkatan Mitigasi). }\end{array}$ \\
\hline 2 & $\begin{array}{l}\text { PT Chevron Pacific } \\
\text { Indonesia }\end{array}$ & $\begin{array}{l}\text { Fokus jaga kegiatan operasi, pencegahan untuk mengurangi risiko paparan Covid-19, } \\
\text { kesiapsiagaan kondisi darurat, focus keselamatan dan Kesehatan pekerja. }\end{array}$ \\
\hline 3 & Exxon Mobil & $\begin{array}{l}\text { Fokus jaga kegiatan operasi aman dan handal, portofolio bisnis antara hulu dan hilir } \\
\text { harus imbang. Protocol Kesehatan antisipasi covid-19. Panduan keselamatan kerja, } \\
\text { mendukung program pemerintah. }\end{array}$ \\
\hline 4 & British Petroleum & $\begin{array}{l}\text { Bentuk protokol dalam kegiatan operasional perusahaan untuk antisipasi covid- } \\
\text { 19.Program keselamatan bekerja di rumah , batasi kunjungan ke pabrik. }\end{array}$ \\
\hline 5 & $\begin{array}{l}\text { Conocophillips } \\
\text { (Grissik }\end{array}$ & $\begin{array}{l}\text { Memastikan jual beli gas. Melakukan protocol kesehatan, melakukan bekerja dari } \\
\text { rumah dan operasional isolasi terbatas. }\end{array}$ \\
\hline 6 & PT PLN & $\begin{array}{l}\text { Menerapkan prosedur keselamatan dilingkungan kerja, buat panduan pencegahan } \\
\text { penyebaran virus corona.Menerapkan prosedur keselamatan. Memberikan sitimulus } \\
\text { tarif tenaga listrik. }\end{array}$ \\
\hline 7 & $\begin{array}{l}\text { PT Indocemen } \\
\text { Tunggal Prakasa }\end{array}$ & $\begin{array}{l}\text { Membuat pedoman pencegahan dan penangganan covid-19. Menerapkan } \\
\text { kesinambungan bisnis, membuat gugus tugas pencegahan dan penanganan covid-19. } \\
\text { Medical respon team,protokol Kesehatan, buat prosedur pengaturan kerja bergilir. }\end{array}$ \\
\hline 8 & $\begin{array}{l}\text { PT Semen } \\
\text { Indonesia }\end{array}$ & $\begin{array}{l}\text { Membuat Antisipasi scenario the new normal, membuat protokol penangganan } \\
\text { terhadap pencegahan penyebaran covid-19. Membentuk gugus tugas percepatan } \\
\text { penanganan covid-19, mengutamakan keselamatan karyawan dan masyarakat. }\end{array}$ \\
\hline 9 & PT PUSRI & $\begin{array}{l}\text { Mmelakukan pelatihan COVID Drill, membuat scenario kejadian serangan covid-19. } \\
\text { Melakukan pencegahan preventif pencegahan dan pemutusan rantai } \\
\text { penyebaran.Mematuhi protocol kesehatan, penerapan work from home, menjaga } \\
\text { perilaku hidup bersih dan sehat. }\end{array}$ \\
\hline 10 & PT Candra Asri & $\begin{array}{l}\text { Melangsungkan rencana ekpansi kapasitas produksinya, membangun pabrik Metil Tert- } \\
\text { Butil Ether (MTBE) dan proyek Butene-1. Melakukan protocol kesehatan, kebijakan } \\
\text { bekerja dari rumah. }\end{array}$ \\
\hline 11 & PT PAL & $\begin{array}{l}\text { Amankan kesinambungan pekerjaan proyek pembangunan kapal, memastikan bisa } \\
\text { memberikan kontribusi terhadap ketahanan nasional. Menerapkan tanggap darurat } \\
\text { bencana pandemic, penerapan protocol kesehatan yang ketat, peningkatan standar } \\
\text { kebersihan lingkungan maupun personil. }\end{array}$ \\
\hline 12 & PT Polytama & $\begin{array}{l}\text { Memberikan dukungan penanganan covid-19, membagikan ribuan paket suplemen } \\
\text { kepada tenaga medis. Manajemen Pencegahan Covid-19: Mang Covid-19. }\end{array}$ \\
\hline 13 & PT Pupuk Kaltim & $\begin{array}{l}\text { Mendukung penanganan dan pencegahan Covid-19 di kota Bontang, memberikan } \\
\text { bantuan cairan disinfektan, alat penyemprotan, hand sanitizer, alat pelindung diri } \\
\text { (APD), thermo gun, masker N95, wastafel portable. }\end{array}$ \\
\hline 14 & PT Badak LNG & $\begin{array}{l}\text { Fokus pada kegiatan opersional dengan aman. Penerapan pelaksanaan work from } \\
\text { home kecuali terkait dengan proses produksi tetap bekeria dengan protocol Kesehate }\end{array}$ \\
\hline
\end{tabular}


Perusahaan migas mencoba berdamai dan menyesuikan dengan Covid-19. Sejumlah rencana dan adaptasi dilakukan perusahaan migas untuk menjaga kesinambungan bisnis (continuity business).

Untuk kelangsungan bisnis perusahaan migas seperti PT Pertamina, PT Chevron Pacific Indonesia, Exxon Mobil, British Petroleum, Conocophillips dan PT Badak LNG tetap focus kegiatan operasinya, walaupun mengalami kerugian akibat pandemic COVID-19. Penyebab kerugian perusahaan migas, karena over supply minyak dunia akibatnya melemah permintaan, lemahnya harga minyak dan gas dunia, margin yang rendah dari produk kilang, pemangkas produksi minyak dan gas, serta rendahnya permintaan bahan bakar minyak dan pelumas.

Langkah-langkah perusahaan migas dalam menjaga keberlangsungan bisnis :

a. Portofolio usaha hulu dan hilir harus seimbang.

b. Memastikan jual beli migas agar tetap berjalan lancar, dengan cara jangka Panjang.

c. Mengurangi biaya modal, seperti menunda mengeboran cekungan minyak baru.

d. Fokus untuk menjadi operator migas dengan berbiaya rendah.

Untuk perusahaan selain migas tersebut secara umum telah melakukan usaha-usaha untuk kelangsungan bisnisnya, bahkan ada yang bisa memberikan kontribusi terhadap ketahanan nasional, kesinambungan proyek pembangunan dan memberikan sumbangsih kepada masyarakat sekitarnya.

Analisis skenario kelangsungan bisnis dengan prinsip PAMA sebagai sampel PT Pertamina (Persero) atau Usaha Migas, COVID19 telah mengganggu supply chain (rantai pasokan). Impact level of COVID-19 pada level moderate risk, impact on operation supply chain terganggu (masih ada sumber alternatif), mitigasinya agar kesinambungan bisnis :

- Menerapkan rencana diversifikasi pemasok

- Pertahankan kontak yang sering dengan pemasok utama

Impact level high risk, impact on operation supply chain crude oil terganggu (gangguan rantai pasokan total; tidak ada sumber alternatif), mitigasinya agar kesinambungan bisnis :

- Evaluasi kembali kapasitas produksi

- Evaluasi kembali kapasitas pemasok (harian).

Secara umum, perusahaan-perusahaan itu telah menunjukkan upaya-upaya penerapan prinsip PAMA. Dari pengamatan dan analisis terhadap Emergency Response Plans (ERP) dan upaya untuk menjaga kelangsungan bisnis masing-masing perusahaan ditengarai: a. Menyelenggarakan program-program kedaruratan sesuai dengan situasi dan kondisi perusahaan, lingkungan sekitar dan kebutuhan masyarakat yang berada disekitar perusahaan.

b. Program-program yang menjaga kelangsungan bisnis didasarkan pada kemampuan perusahaan dan inti bisnisnya masing-masing. Perusahaan telah berusaha untuk tidak melakukan Putus Hubungan Kerja besar-besaran, sebaliknya perusahaan justru merumuskan kebijakan-kebijakan guna melindungi seluruh Sumber Daya Manusianya dari terjangkitnya Coronavirus pada dirinya. Hal itu menunjukkan bahwa perusahaan berusaha keras menjaga kelangsungan bisnisnya, karena Sumber Daya Manusia merupakan salah satu faktor penentu yang harus dipertahankan dan dilindungi. Selain itu, perusahaan juga terus berusaha untuk fokus dan melakukan efisiensi, agar bisnis yang dikelola dapat terus bertahan di masa pandemi sambil terus mempersiapkan upaya-upaya menjaga keberlanjutan usaha paska pandemi.

\section{KESIMPULAN}

Dari uraian di atas, dapat disimpulkan sebagai berikut:

a. 14 perusahaan tersebut telah memiliki Emergency Response Plans (ERP) dengan program-program kedaruratan yang telah dilakukan, meski tampak belum ada kesatuan standar diantara 14 perusahaan tersebut.

b. 14 perusahaan tersebut telah melakukan program-program untuk menjaga keberlangsungan usaha berdasarkan kemampuan perusahaan dan inti bisnisnya masing-masing.

\section{UCAPAN TERIMA KASIH}

Kami ucapkan terima kasih kepada keluarga yang telah mendukung dalam pembuatan materi ini dan kami ucapkan terima kasih kepada Panitia Forum Pertemuan dan Presentasi IImiah Standarisasi (PPIS) BSN.

\section{DAFTAR PUSTAKA}

--. (2020). Business continuity management. Retrieved Agustus 17, 2020 from: https://interpromusa.com/how-a-pandemiis-prof-to-your-business-continuityPudding

--. (2020).Covid-19: Managing risks and ensuring business continuity, Retrieved Agustus 17, 2020 
http://drive.google.com/drive/folders/libbzC DS X3JXKKDydOo/R54PDUvjvArN?usp=sharing

--. (2020). Managing process safety during the covid-19 pandemic. Retrieved Mey 20, 2020 from https://bit.ly/ISCcoveid

Badan Standardisasi Nasional. (2018). SNI ISO 45001: 2018-Standar Sistem Manajemen Keselamatan Kerja (SMK3) [Occupational Health and Safety Management System], Requirement with guidance for use. Badan Standardisasi Nasional. (2020).

Draft ISO 45005, COVID-19 Management System. Jakarta.

British Petroleum. (2020). Bp dan exxon bentuk protokol antisipasi corona

Retrieved from https://ekonomi.bisnis.com/read/20200323 /44/1216952/bp-dan-exxon-bentukprotokol-antisipasi-corona

Brauer, Roger L. (2016). Safety and health for enginers, New York, Van Nostrand Reinhold.

BS ISO 22301: 2019. (2019). Security and resilience, business continuity management system, requirements. Switzeland: BSI Standard Limited.

Crowl, Daniel A \&Louvar, Joseph F. (2019). Chemical process safety fundamentals with applications. New Jersey: Pearson Education Inc.

Denton, Jhon WH (2020). International chamber of commerce (icc), covid-19 business continuity guide. Retrieved March 4, 2020 from https://iccwbo.org/publication/covid19-business-continuity-guide/

Exxon Mobil. (2020). Retrieved August 3, 2020 from https://ekonomi.bisnis.com/read/20200803 /44/1274496/di-masa-pandemiexxonmobil-danchevron-fokus-jagakegiatan-operasi

Jatmiko, A. (2020). Conocophillips (Grissik). Retrieved April 13, 2020 from https://katadata.co.id/agungjatmiko/energi/ 5e9a41c9c3c2b/conocophillips-kaji-efekcovid-19-pada-permintaan-gas-blokcorridor.

Kementerian Kesehatan RI. (2020). Pedoman pencegahan dan pengendalian coronavirus disease (covid-19) revisi ke 5. Retrieved from: https://covid19.go.id/p/protokol/pedomanpencegahan-dan-pengendaliancoronavirus-disease-covid-19-revisi-ke-5

Liputan 6. (2020). Bantu cegah penularan covid 19 chandra asri kirim bantuan ke bnpb
Retrieved from https://www.liputan6.com/bisnis/read/4212 117/bantu-cegah-penularan-covid-19chandra-asri-kirim-bantuan-ke-bnpb

Lukiawan, Reza. (2018). Kesiapan organisasi dalam implementasi standar ISO 37001 (studi kasus di UD $X$ dan Dinas Y) [The Readiness of organization In Implementation of Standard ISO 37001] (Case study in venture $X$ and office $Y$ ).

Nadesul,Handrawan. (2020). COVID-19 Bagaimana Agar Tidak Tertular [How not to be infected] Jakarta.

National Fire Protection Associasion (NFPA). (2010). Standard on disaster/ emergency management and business continuity programs. Massachusetts USA: webnfpa.org, Quincy.

Penington, Tess. (2020). Panduan kesiapsiagaan hadapi virus corona [the coronavirus preparedness handbook]. Jakarta: PT Kompas Media Nusantara.

PT Badak LNG. Badak Ing terapkan status waspada tinggi covid-19. (2020).

Retrieved

https://kaltimtoday.co/badak-Ing-terapkanstatus-waspada-tinggi-covid-19/

PT Candra Asri Petrochemical. (2020). Antisipasi penyebaran Chandra asri donasikan 20000 alat tes rapid virus corona. Retrieved from https://industri.kontan.co.id/news/antisipasi -penyebaran-chandra-asri-donasikan20000-alat-tes-rapid-virus-corona.

PT Chevron Indonesia. (2020). Hadapi pandemi chevron pacific indonesia utamakan keselamatan karyawan. Retrieved May 29, 2020 from https://industri.kontan.co.id/news/hadapipandemi-chevron-pacific-indonesiautamakan-keselamatan-karyawan

PT Indocemen Tunggal Prakasa Tbk (2020). Retrieved August 2020, http://www.indocement.co.id.

PT. PAL (2020). Pal amankan kesinambungan pekerjaan di tengah pandemic covid 19 Retrieved August 17 , 2020 from https://pal.co.id/2020/08/publikasi/artikel/p al-amankan-kesinambungan-pekerjaan-ditengah-pandemi-covid-19/

PT Pertamina. (2020). Komitmen pertamina bergotong royong lawan covid 19. Retrieved August 12, 2020 https://www.pertamina.com/id/newsroom/energia- news/ke-to-p-ra-kkomitmen-pertamina-bergotong-royonglawan-covid-19 
PT PLN. (2020). Cegah corona ini kebijakan internal dan eksternal di lingkungan pln . Retrieved March 8, 2020 https://www.liputan6.com/news/read/4196 845/cegah-corona-ini-kebijakan-internaldan-eksternal-di-lingkungan-pln

PT Polytama Propindo. (2020). Polytama propindo berikan dukungan penanganan covid19. Retrieved May 21, 2020 from https://investor.id/national/polytamapropindo-berikan-dukungan-penanganancovid19

PT Pupuk Kaltim. (2020). Covid 19. Retrieved August, 2020 from https://www.pupukkaltim.com/id/covid-19-1

PT Pupuk Sriwijaya. (2020). Retieved August 12 , 2020
PT Semen Indonesia (Persero). Retrieved March 2, 2020 https://money.kompas.com/read/2020/05/2 1/034923726/hadapi-new-normal-ini-yangdilakukan-semen-indonesia dan Retieved May 15, 2020 https://jatimnow.com/baca-26654-semenindonesia-siap-terapkan-the-new-normal

Simak. (2020). Panduan Protokol Kesehatan Pencegahan Covid-19 untuk Sambut New Normal. Retrieved from: https://www.kompas.com/tren/read/2020/0 5/18/103200465/simak-panduan-protokolkesehatan-pencegahan-covid-19-untuksambut-new?page=alln 